\title{
A Research on Cooperative Learning in College English Teaching
}

\author{
Xiaohui XU \& Lei WANG \\ Department of Basic Course, Jinan Engineering Vocational and Technological College, Jinan, China
}

\begin{abstract}
On the basis of analysis of the present situation of English Teaching in Higher Vocational Colleges, this paper explores on the model of cooperative learning in College English teaching. The structure and process of teaching model of cooperative learning are put forward: 1. Bejing specific in teaching objectives; 2. Reasonable grouping; 3. Constructing tasks and structure of cooperation and giving detailed instructions; 4. Students' cooperative learning and teachers' monitoring and intervention; 5. Teachers' and students' evaluation and reflection on cooperative learning. This paper discusses the enlightenment of the teaching model of cooperative learning in higher vocational English teaching: 1. It correctly handles the relationship between teachers and students, and pays attention to cultivate the students' language application ability; 2. It provides English learning opportunities through multiple channels, and stimulate students' English learning motivation.
\end{abstract}

KEYWORDS: cooperative learning; college English teaching; higher vocational education

\section{INTRODUCTION}

China's higher vocational education has entered a new stage of rapid development since the 1990s, which aroused people's great attention. The students enrolled in higher vocational colleges (my college, for instance) share the following characteristics: their English score is relatively lower, learning interest is not strong, English foundation is not solid, and education background is uneven, which bring new challenges to the current college English teaching.

English teaching has a long history in our country as well as abroad. The world demand for English has promoted the development and reform of college English teaching. However, along with the popularization of higher education, the limitations and insufficiencies of traditional classroom teaching structure since Comenius have been often criticized. Many students show emotions of disappointment and weariness because of poor academic performance in the class and having no chance of performance and being recognized. So looking for a kind of effective teaching strategies to improve the teaching quality, creating an effective way of learning situations, and forming an integrated class organization structure have become a general concern for the educators.

\section{THE STRUCTURE AND PROCESS OF THE TEACHING MODEL OF COOPERATIVE LEARNING}

Since the beginning of the 20th century, the understanding of learning experienced the evolution from behaviorism, cognitivism to constructivism. Wittrock put forward generative learning theory. The core is: The correlation between learners' prior knowledge and external stimulation forms the learners' tendency to focus on and process the stimulation, prompting learners to have the relationship construction of relevant prior knowledge with new information, and with the help of sensory experience and logical systems or external feedback, the learners test their new knowledge to decide whether to internalize it, check it again, or give it up[1].The main advocate for social constructivism is Vygotsky. He deeply realized that, the children's thinking development was built on the basis of dialogue with people of higher level [2].

Cooperative Learning started in the United States in the early 1970s, and made substantial progress from the mid 1970s to the mid 1980s. Cooperative learning can improve classroom atmosphere, improve students' grades, and help the students form a good non-cognitive quality. It has been praised as "one of the most important and successful teaching reform in the recent more than ten years."[3] 
Cooperative learning can help students to cultivate the ability of access to information, and is good for students to form and develop their self-awareness. In cooperative learning, students interactive, share information, and at the same time they love and help each other and have emotional communication[4].

The creator of Learning Together (LT) ---the Johnson brothers (Johnson, D.W.\& Johnson, R.T.) in the Cooperative Learning Center of The university of Minnesota in the United States believes "Cooperative learning is a kind of learning style to apply team in the teaching, to make the students participate in learning activities together, and to promote their own as well as others' learning " [5].

In order to guide teachers to implement cooperative learning, the Johnson brothers have made clear about the 18 specific steps needed to be completed by teachers[6]. It is not simply to use some specific strategies for teachers to make the cooperative learning to be effective. The key lies in the flexibility to use its basic principles, and then making use of it creatively according to the actual need. Based on the five elements of LT, the 18 specific steps, and years of higher vocational English teaching practice, the author puts forward the structure and process of LT teaching model.

\subsection{In the preparation stage before class, the tasks teachers need to complete}

\subsubsection{Be Specific in teaching objectives}

One kind is academic objective and preparation of such objective should fit the students' level. Another kind of objective is about cooperation skill, so teachers should be clear about what cooperation skills are in the class. From the view of the constructivist learning, English teaching objectives need to meet four requirements: i Giving full consideration to students' needs and knowledge level; ii having the theme of pertinence and maneuverability; iii Taking into account the linguistic knowledge, skills and content at the same time; iv Having the characteristic of being systematic and logical.

\subsubsection{Be reasonable in grouping.}

Generally speaking, it's appropriate to have 2-6 members for an English cooperative learning team. Teachers are advised to use heterogeneous group. That is to assign the high, medium and low level student into the same group. In the heterogeneous group, there will be more collaborative thinking, more information input and output, and will generate more views, all of which contribute to improve the depth of student understanding, quality of reasoning and to maintain the accuracy of long-term memory.

\subsection{In the class implementation stage, cooperative}

learning consists of three basic components

\subsubsection{Construct tasks and cooperation structure and to introduce in detail}

In the formal teaching, according to their own teaching design, the teacher May start to introduce cooperative learning at the very beginning, and may also introduce cooperative learning after the class teaching. According to pre-class preparation each team has quietly and orderly sat down in the specified location and get the material prepared by teachers. Teachers also need to set forth in detail the learning task, cooperation rules and requirements, criteria of reaching the cooperative learning objectives, so that students can identify what learning goals to achieve in the group learning and how to achieve the goals.

In cooperative learning, first teachers give brief direct teaching focusing on such difficulties of learning content as the key concepts, principles, grammars, sentence structures and so on. The purpose is to help students to clear the difficulties and obstacles that may be encountered while selflearning. After being clear about the learning task, teachers ask students to discuss in small groups. Teachers should assign roles to promote students' positive interdependence, establish individual responsibility, and encourage students carry out cooperative learning on the basis of individual learning and individual thinking. Without the independent thinking, and without forming their own ideas and understanding, students can only become audiences in cooperative learning.

\subsubsection{Students have cooperative learning and teachers monitor and intervene}

Through teachers' direct teaching and the organization and interpretation of cooperation, students are clearer about the group tasks, group goals, and cooperation methods. Students begin the group discussion in cooperative learning and teachers need to complete the following tasks: Monitor students' behavior; Provide assistance; intervene and teach cooperation skills. These three tasks exist at the same time and having organic combination with each other.

\subsubsection{Teachers and students evaluate and reflect on cooperative learning together}

\section{(1) Learning to summarize}

After the end of the cooperative learning, students should summarize what they have learned themselves, and can understand the knowledge to be used in the future.

(2) Evaluation of students' learning

Scoring in the group evaluation must be based on the encouragement principles. The average score of 
each group member is the group score. The purpose is to eliminate psychologically the invisible gap between those introverted students with unsatisfactory grades and the outgoing students with good grades, and thus to tap their potential to learn English.

(3) Group Reflection includes both the reflection on the completion of the learning task and the organization of group cooperation. They can be assessed by the students themselves while teachers and students can also have a common assessment, but students should play a major role. Affirm where is good during assessing while learning lessons from where is not satisfactory and suggest improvements. If teachers and students can work together to establish a learning log and diary, they can link the teaching contents in cooperation class with students' emotion and life experiences. Thus make cooperation and learning gradually go into the daily lives of individuals[7].

\section{THE ENLIGHTENMENT OF LT TEACHING MODEL FOR HIGHER VOCATIONAL ENGLISH TEACHING}

\subsection{Cooperative learning strategies handle appropriately the relationship between teachers and students, and pay attention to cultivate the students' language application ability}

Compared with the traditional teaching, cooperative learning strategies pays more attention to students' activities to meet the psychological needs of students, and put teaching emphasis on students' learning. On the surface, teachers have really lost a lot of the so called "authority" of the traditional teaching system, but in fact the teachers have more important role and greater responsibility. Teachers should teach, arouse students' interest and motivation, encourage each student to maximize access to development, and be good at communicating with students to coordinate each group's activities, endorse or reward students and groups, and encourage students to take the initiative to acquire knowledge. Through these activities, teachers play a real leading role, and students are also made a real master in their study.

Constructivism believes that the premise of learning is that the learning contents trigger learner's attention, and then make it tend to form the meaning construction of learning content. In other words, bringing the students into situations created around the theme of learning in order to activate their prior knowledge and learning motivation is one of the prerequisites to achieve the goal of classroom teaching. In the classroom teaching, effective leading situation should be closely linked to class topics, guide the student to selective attention, activate students' relevant knowledge and promote its reconstruction. For example, higher vocational English Career Development Training---the English practice in Serbia E763 expressway construction project of Shandong Expressway Group. see Table 1.

Table 1. the English practice in Serbia E763 expressway construction project of Shandong Expressway Group

\begin{tabular}{|c|c|}
\hline Project1 & 1. English practice in the preparation stage \\
\hline Situation & $\begin{array}{l}\mathrm{Mr} \text { Li is sent to Serbia for construction } \\
\text { preparation }\end{array}$ \\
\hline Act & $\begin{array}{l}\text { 1.Teacher demonstrates } 154 \text { sentences of } \\
\text { Overseas Engineering English } \\
\text { 2. Group simulation to communicate with new } \\
\text { colleagues } \\
\text { 3. Team work to fill in the English engineering } \\
\text { contract together }\end{array}$ \\
\hline & in the construction stage \\
\hline Situ & $\begin{array}{l}\text { Serbia E763 expressway construction get } \\
\text { started on time, and Mr. Li is one of the Project } \\
\text { construction workers }\end{array}$ \\
\hline Ac & $\begin{array}{l}\text { 1.Teacher demonstrates } 270 \text { sentences of } \\
\text { Overseas Engineering English } \\
\text { 2. Group discussion to understand English } \\
\text { drawings } \\
\text { 3. Team work to prepare construction plans } \\
\text { and schedules }\end{array}$ \\
\hline & 3. English practice in the completion stage \\
\hline Situ & $\begin{array}{l}\text { Serbia E763 expressway construction is } \\
\text { completed successfully, and } \mathrm{Mr} \text {. Li is one of } \\
\text { the Project construction workers }\end{array}$ \\
\hline Activities & $\begin{array}{l}\text { 1. Teacher demonstrates } 76 \text { sentences of } \\
\text { Overseas Engineering English } \\
\text { 2. Team work to write English memo and work } \\
\text { log } \\
\text { 3. Team work to prepare celebrating dinner }\end{array}$ \\
\hline
\end{tabular}

\subsection{Cooperative learning strategies provide multi- channel English learning opportunities and stimulate students' motivation to learn English}

Motivation allows us to turn from boredom to interest like the engine and the steering wheel on a motor vehicle. Gardner thought that the motivation to learn a foreign language should include four aspects: learning objectives - learning effort the desire to achieve the learning objectives and learning attitude. Learning foreign language with motivation is very effective, while learning foreign language without motivation is not effective because it usually regard the foreign language learning as a burden.

Teachers can organize a variety of English activities through the second class to increase students' chances to have access to English and enhance English learning atmosphere. Under the leadership of teachers, students set up English corner, establish English clubs and societies, watch English movies, appreciate English and American literature and organize colourful English contests, such as English speech contest, English writing contest, English Song Contest, English movie 
dubbing contest and so on. The college builds a full range of English learning environment for students in which teachers actively promote and students actively take part in. Students unwittingly created intimacy and interest for English. The input and output of English have also got a full range of enhancement.

\section{CONCLUSIONS}

This paper introduces the advanced foreign theory of cooperative learning in college English teaching. Numerous studies show that cooperative learning in higher vocational English is consistent with the progress of era and social development. It captures the major issue of improving the efficiency of school education and the quality of people. The teaching model of cooperative learning is extremely rich in content, and has an active role in improving students' English, forming students' positive attitude towards the English disciplines and developing their critical thinking skills, etc. It is a better solution to the hot topics of education reform in the world such as how to make students learn to master, be good at learning, like to learn, learn happily and so on. It make teaching get a big step forward in the path of socialization, and represent the direction of the future development of the modern education system.

\section{ACKNOWLEDGEMENTS}

The research work was supported by Shandong province education" The twelfthfive-year" plan project "the application of cooperative learning in highervocational English teaching" (project number: 2013 GG 032)

\section{REFERENCES}

[1] Tobias S. Generative learning theory, paradigm shifts, and constructivism in educational psychology: A tribute to Merl Wittrock. Educational Psychologist, 2010, 45(1): 5154.

[2] Wittrock M C. Learning as a generative process. Educational Psychologist, 2010, 45(1) : 40-45.

[3] Johnson, D.W., \& Johnson, R. Cooperation and Competition: Theory and Research, Edina, $M N$ : Interaction Book Company. pp 23-26, 1989.

[4] Robert E.Slavin. Cooperation Learning. Review of Educational Research Summer, Vol. 50, No.2, 1980.pp 51-52.

[5] Tan Wang. An Analysis of the Theoretical Basis of Cooperative Learning. Curriculum, Teaching Materials and Methods, 2005 (1): 31.

[6] Xinchun $\mathrm{Wu}$, Lin Guan. Cooperative Learning and Classroom Teaching. People's Education Press, 2013.pp167-168.

[7] Tan Wang. Cooperative Learning-Principles and Strategies. Beijing: Academy Press, 2001.pp76-79. 